\title{
Analisis Perilaku Pengguna Dalam Pembelian Item Virtual Pada Game Online
}

\author{
Rina Yulius \\ Program Studi Teknik Komputer, Sekolah Tinggi Teknologi Payakumbuh \\ e-mail: rinayulius@sttpyk.ac.id
}

\begin{abstract}
Abstrak
Game online mengandalkan penjualan item secara virtual guna menghasilkan pendapatan yang lebih besar. Minat pengguna game online berbeda-beda dalam melakukan pembelian. Tujuan dari penelitian ini adalah untuk menguji faktor-faktor yang mempengaruhi perilaku pengguna dalam pembelian item virtual pada game online. Metode pengambilan sampel menggunakan simple random sampling dengan alat ukur berupa skala Likert. Jumlah subjek penelitian ini adalah 300 pengguna game online di Indonesia. Sampel penelitian dianalisis menggunakan structural equation modeling (SEM) guna mengidentifikasi faktor-faktor perilaku pengguna dalam pembelian item virtual pada game online.
\end{abstract}

Kata kunci: item virtual, game online, SEM

\begin{abstract}
Online games increasingly sell virtual items to generate more income. Intent to purchase virtual items is different among gamers. This study aims to evaluate factors affecting gamer's behavior and how to predict it toward purchasing virtual items. Simple random sampling was used in explanatory research using five-point Likert scale which was distributed to 300 users of online game in Indonesia. The process of analyzing data using structural equation modeling (SEM) to identify factors affecting user behaviors toward purchasing in virtual worlds.
\end{abstract}

Keywords: virtual item, online game, SEM 